\title{
Reinterpreting the age of the uppermost 'Old Red Sandstone' and Early Carboniferous in Scotland
}

\author{
Marshall, J.E.A. ${ }^{1}$, Reeves, E.J. ${ }^{1}$, Bennett, C.E. ${ }^{2}$, Davies, S.J. ${ }^{2}$, Kearsey, T.I. ${ }^{3}$, Millward, D. ${ }^{3}$, Smithson, T.R. ${ }^{4}$ \\ and Browne, M.A.E. ${ }^{3}$ \\ ${ }^{1}$ School of Ocean and Earth Science, University of Southampton, National Oceanography Centre, \\ European Way, Southampton, SO14 3ZH, UK, '2 School of Geography, Geology and the Environment, \\ University of Leicester, University Road, Leicester, LE1 7RH, UK., ${ }^{3}$ British Geological Survey, The Lyell \\ Centre Edinburgh EH14 4AP, Scotland, ${ }^{4}$ Department of Zoology, Downing Street, University of \\ Cambridge, Cambridge, CB2 3EJ, UK \\ Email jeam@soton.ac.uk
}

KEY WORDS: Devonian, Carboniferous, tetrapods, palynology, Ballagan

In Scotland the base of the Ballagan Formation has traditionally been placed at the first grey mudstone within a contiguous Late Devonian to Carboniferous succession. This convention places the DevonianCarboniferous boundary within the Old Red Sandstone Kinnesswood Formation. The consequences of this placement are that the tetrapods from the Ballagan Formation were dated as late Tournaisian in age and that the ranges of typically Devonian fish found in the Kinnesswood Formation continue into the Carboniferous. The Pease Bay specimen of the fish Remigolepis is from the Kinnesswood Formation. Comparisons with its range in Greenland, calibrated against spores, shows it to be Famennian in age. Detailed palynological sampling at Burnmouth from the base of the Ballagan Formation proves that the early Tournaisian spore zones ( $\mathrm{VI}$ and $\mathrm{HD}$ plus $\mathrm{Cl} 1$ ) are present. The Schopfites species that occurs through most of the succession is $S$. delicatus rather than S. claviger. The latter species defines the late Tournaisian CM spore zone. The first spore assemblage that has been found in upper 'ORS' strata underlying the Ballagan Formation (Preston, Whiteadder Water), contains Retispora lepidophyta and is from the early latest Famennian LL spore zone. The spore samples are interbedded with volcaniclastic debris which shows that the Kelso Volcanic Formation is, in part, early latest Famennian in age. These findings demonstrate that the Ballagan Formation includes most of the Tournaisian with the Devonian-Carboniferous boundary positioned close to the top of the Kinnesswood Formation. The Stage 6 calcrete at Pease Bay can be correlated to the equivalent section at Carham showing that it represents a time gap equivalent to the latest Famennian glaciation(s). Importantly some of the recently described Ballagan Formation tetrapods are older than previously dated and now fill the key early part of Romer's Gap.

It has been an accepted view for over 75 years that (e.g. Westoll, 1951; Waterston, 1965; Browne et al. 2002; Read et al. 2002) the uppermost part of the 'Old Red Sandstone' (now the Kinnesswood and older formations) in Scotland and the Scottish Borders (Fig. 1) is Carboniferous in age. This is fundamental for understanding where to place the Devonian-Carboniferous boundary and its relationship to palaeoenvironmental change within this interval. Importantly, the Early Carboniferous Ballagan Formation (Fig. 2) in Scotland contains a number of globally significant fish, tetrapod and arthropod faunas (Smithson et al. 2012; Clack et al. 2016) so understanding their time relationships is fundamental to understanding their evolutionary relationships. Following ongoing research on the 
Late Devonian-earliest Carboniferous rocks in Central Scotland and the Borders as part of the TW:eed Project (Tetrapod World: early evolution and diversification) coupled with new integrated palynological and fish occurrences in East Greenland this age assignment can be questioned. This contribution will show that these hitherto earliest Carboniferous red bed sections are demonstrably Devonian in age and that a full Tournaisian section is present in the Ballagan Formation of Scotland. A number of field sections in Central Scotland and the Borders were investigated during the TW:eed Project and here we report on those from Pease Bay, Burnmouth and along the Whiteadder Water at Preston (Fig. 1).

\section{Historical Context}

In any major reinterpretation of this kind it is important to understand the historical roots as to how and why this Early Carboniferous consensus age for the uppermost ORS (Old Red Sandstone) was achieved. The first documented discussion (Anon 1939) as to the possibility of a Carboniferous age for the uppermost ORS was at the 1939 British Association meeting (Dundee) when there was a scheduled discussion meeting on 'the boundary between the Old Red Sandstone and the Carboniferous'. However, the start of this BA meeting coincided with the German invasion of Poland and, with it, a time of considerable national uncertainty. Added to this was the chaos of the evacuation of the local children, a general transport requisition and UK-wide troop mobilisation. So, the organisers decided to halt the meeting early on the $3^{\text {rd }}$ September and the ORS-Carboniferous boundary discussion that was scheduled for the $5^{\text {th }}$ September never took place. However, contributions were taken as read and reported without the merit of having had the scientific discussion. They were published as summaries (e.g. Westoll 1940) by six of the intended contributors (G. Hickling missing) who were a singularly prominent group of geologists and palaeontologists (W.Q. Kennedy, T.N. George, W.T. Gordon, T.S. Westoll, V.A. Eyles and M. Macgregor). Their views were that a practical boundary for the base of the Carboniferous was at the lowest shale-cementstone horizon but that this, particularly in the West of Scotland would include beds that lithologically would be regarded as Upper Old Red Sandstone. These West of Scotland sections (Eyles et al. 1949) being atypical in that they show an intercalation of intervals of cementstones and 'ORS' (red sandstone with calcrete nodules), i.e. the Kinnesswood Formation. These contributors were well aware that this was purely a lithostratigraphical definition and a practical convention. However, Westoll, as a vertebrate palaeontologist, reproduced the then new fish zonation of Säve-Söderbergh (1934) from East Greenland and noted the common fauna to Scotland and hence a correlation between the Phyllolepis Series and the highest fossiliferous ORS from Dura Den (Fife) and Rosebrae (Moray) in what were apparently contiguous sequences. Westoll's argument being that since both Dura Den and Rosebrae were only a little below the accepted base of the Carboniferous then the overlying Remigolepis and Arthrodire Series in East Greenland might be contemporaneous with the lowest Carboniferous elsewhere (Fig. 3). This implied that the important, and, at that time, the earliest known tetrapod fauna from East Greenland was, in fact, Carboniferous in age. In other contributions Westoll generally referred to these tetrapods as Upper Devonian or high Upper Devonian or ? Early Carboniferous (both ages are quoted in Westoll 1938) or lowest Carboniferous (Westoll 1943). Säve-Söderbergh (1934) had very much invited this interpretation by noting that the Phyllolepis Series was the highest Upper Devonian yet known with the Remigolepis and Arthrodire (Groenlandaspis) Series representing even younger Devonian rocks that were, as yet, unknown from elsewhere perhaps corresponding to a gap in these other sequences. Westoll, recognising that the ORS to Carboniferous transition in Scotland was contiguous, simply moved the Remigolepis and Arthrodire Series into the Carboniferous. In any event, we can speculate that Westoll was probably always going to give a determined response as it 
was a member of the Stockholm School (of vertebrates, Schultze 2009) working in Greenland who has pre-empted the publication (Patterson \& Fortey 1999) of Westoll's own thesis on Permian fish from County Durham. A response to this reassignment of the East Greenland tetrapods to the Carboniferous was only made in 1948 by Jarvik, at the request of Säve-Söderbergh who had been debilitated by tuberculosis (Jarvik 1996) from 1937 until his premature death in 1948. Jarvik (1948) gave a critical discussion of the age of the East Greenland tetrapods by systematically going through each 'Series' and its fauna. This expressed disappointment that Westoll's supposition of a possible earliest Carboniferous age for the tetrapods had been reiterated in textbooks such as Romer's Vertebrate Paleontology (Romer 1945). Jarvik (1948) based his arguments on the occurrences of the complete fauna bar tetrapods (i.e., Remigolepis, Bothriolepis, Phyllolepis, rhizodonts and holoptychiids) and demonstrated that none of these forms were known from Carboniferous sections elsewhere in the world. This correlation was then reiterated (Jarvik 1950) against the more precisely defined DevonianCarboniferous boundary of the Heerlen Congress (Jongmans \& Gothan 1937). In reality, these comparisons were always limited by fossil fish being restricted to certain facies so that the most important comparative sections were in Belgium and the Baltic. To an extent this was based on accepting that certain fish groups were restricted to the Devonian (e.g. placoderms), something that is now accepted (Sallan \& Coates 2010) but was at that time not evident, with the possibility, then as now, for the existence of hold-over taxa (i.e. dead clades walking). This situation of these somewhat imprecise and ambiguous ages (e.g. Jarvik 1961; Bütler 1961; Nicholson \& Friend 1976; Olsen \& Larsen 1993) for the East Greenland tetrapods continued without any additional information such that the clarity of these initial correlations by Jarvik $(1948,1950)$ was lost. This introduced element of uncertainty has meant that subsequently the tetrapods tended to be attributed a rather ambiguous age of around the Devonian-Carboniferous boundary.

The dating and recognition of a defined Devonian-Carboniferous boundary was only resolved in East Greenland in 1999. This renewed interest was driven by the re-dating of the sections based on palaeomagnetism and geochronology (Hartz et al. 1997) that indicated the tetrapods were Early Carboniferous and potentially as young as Viséan in age which proved somewhat controversial (Stemmerik \& Bendix-Almgreen 1998; Hartz et al. 1998). The problem was solved by palynology (Marshall et al. 1999; Streel \& Marshall 2006; Astin et al. 2010). This gave a clear position for the Devonian-Carboniferous boundary within the Obrutschew Bjerg Formation (on Stensiö Bjerg) and above the ranges of both Remigolepis (by $150 \mathrm{~m}$ ) and the in situ tetrapod Acanthostega (by $230 \mathrm{~m}$ ) that are pre-latest Famennian in age.

It is from this time that there was a divergence of view between the Stockholm School who regarded Remigolepis and related fish and tetrapod faunas as clearly Devonian in age (Fig. 3) whereas the same faunas, despite being absent from Scotland, were attributed to the early Carboniferous (Westoll 1951). For example, Waterston in the Geology of Scotland (1965, p. 302) simply notes that the Upper ORS persisted into the Tournaisian in Scotland. The rationale being that in Greenland the Remigolepis Zone was younger than anything known from Europe and hence fell into the Carboniferous. Similarly, Westoll compiled (1977) the sections on Northern Britain for the Devonian Special Report of the British Isles. The Ballagan Formation section from Pease Bay to Cove in the Borders was regarded as particularly important as it had cementstones which were dated as being in the CM spore zone (late Tournaisian) by Neves et al. (1973), succeeded by the Horse Road and Heathery Heugh Sandstones that were regarded as similar in facies to the Upper ORS. The Horse Road Sandstone was noted as containing lower Pa (sic) zone spores and was equivalent to Tn2 or Tn3 in Belgian nomenclature (Hance et al. 2006). In fact, this is the Pu spore zone named after Lycospora pusilla which has an inception at about the Tournaisian/Viséan boundary. However, it should be noted that Lycospora pusilla had not been reported by Clayton (1971, p. 597) from the Horse Road Sandstone at outcrop 
but only in the Birnieknowes Borehole from below the base of a ?Horse Road Sandstone correlative. More recent work by Stephenson et al. (2004a) gives only a single occurrence of Lycospora pusilla and this is from above the Horse Road Sandstone Member. This correlation and the name error of Pa for Pu zone has been reported in subsequent accounts of the section (Grieg \& Davies in Friend \& Williams 1978; Dineley \& Metcalfe 1999).

In part, this view of a young 'ORS' was significantly influenced by the palynological work of Clayton (1971) on the Ballagan Formation cementstone section at Pease Bay. The section was recognised as thin with the then unnamed CM spore zone spores (Schopfites claviger and Auroraspora macra) being regarded as from the upper part of the Ballagan in what was seen as a contiguous section. Clayton discussed two possibilities, firstly that the ORS beneath the cementstones was in the early Carboniferous or secondly that the 'lower' Tournaisian was extremely condensed. This discussion was always influenced by the consensus (Westoll 1951) that the top of the Kinnesswood Formation was well within the Tournaisian. In addition, stratigraphic palynology was in its infancy such that there few independent dated Tournaisian sections with which it could be compared. This placement of the CM spore zone in the later part of the Tournaisian has been generally adopted (e.g. Stephenson et al. $2002,2004 a, b)$. Independent age evidence for the inception of Schopfites claviger comes from Ireland where in the Baunta borehole (Keegan 1981; Higgs et al. 1988) there is a CM assemblage in the lower part of the Polygnathus mehli conodont zone. In the Tatestown prospect boreholes of County Meath, Ireland, the base of the CM spore zone is placed (Keegan cited in Andrew \& Poustie, 1986) in the slightly older Lower Pale Beds from the underlying Pseudopolygnathus multistriatus conodont zone. There is a further constraint from Cumbria where Schopfites delicatus but not S. claviger occurs in the lower part of the Pinskey Gill Formation (Johnson \& Marshall 1971; Welsh 1979; Holliday et al. 1979) together with conodonts (Varker \& Higgins 1979; Higgins \& Varker 1982; Varker \& Sevastopulo 1985) that are ascribed to Fauna A of mid Courceyan age (i.e. mid Tournaisian). Schopfites claviger does occur in the Stone Gill Limestone Formation that together with the underlying Marsett Formation conglomerates unconformably overlie the Pinskey Gill Formation (Waters et al. 2011). The conodonts in the upper part of the Stone Gill Limestone Formation are from the Chadian Taphrognathus Zone. This occurrence of the Chadian, which is the regional substage at the base of the Viséan, is confirmed by the presence of Lycospora pusilla (i.e. Pu Zone) in the Stone Gill Limestone Formation. This places the delicatus to claviger transition in the mid to late Tournaisian interval although Welsh (1979) regards $S$. delicatus as a variant of $S$. claviger and places the base of the $\mathrm{CM}$ zones at the inception of the former with its earlier species inception.

The CM spore zone has become effectively synonymous with the Ballagan Formation with its somewhat monotonous palynological assemblage. This assemblage has been reported from throughout the Ballagan Formation (Sullivan 1968; Clayton 1971; Neves et al. 1973; Neves \& loannides 1974 ) in terms of both stratigraphic and geographic range. The most detailed recent accounts are by Stephenson et al. (2002, 2004a, b) where range charts detail the occurrence of Schopfites claviger throughout the formation including the Glenrothes, Birnieknowes and East Dron boreholes (e.g. Millward et al. 2018) where the succession continues down to the Kinnesswood Formation. At Burnmouth Schopfites claviger is reported (Scott et al. 1984) from $70 \mathrm{~m}$ above the base of the formation to $45 \mathrm{~m}$ below its top.

The current view of stratigraphic nomenclature and spore zonation in the Late Devonian and Early Carboniferous of the Scottish Borders is shown in Fig. 2. It is important to note which spore zones have actually been found in the region (bold) in contrast to the spore zones that have been recognised from sections outside Northern Britain through the same time interval. 


\section{Methods}

All the palynological samples from Burnmouth, Pease Bay and Preston were processed by standard techniques with $5 \mathrm{~g}$ of roughly crushed rock (grey to black or dark green mudstone) treated with $30 \%$ $\mathrm{HCl}$ to remove carbonates, followed by decant washing to neutral $\mathrm{pH}$. They were then demineralised in $60 \% \mathrm{HF}$ followed by decant washing again to neutral and sieved at $15 \mu \mathrm{m}$. The samples were then placed in glass beakers and briefly boiled in $30 \% \mathrm{HCl}$ to solubilise neoformed fluorides that were then removed by diluting into a large volume of water and resieving. The samples were then vialed and strew slides mounted in Elvacite $2044^{\mathrm{TM}}$. Any AOM (amorphous organic matter) was removed from the samples with a 15-30 s treatment using a Sonics and Materials ultrasonic probe followed by resieving at $15 \mu \mathrm{m}$. The AOM preferentially fragments through the action of the probe and can be removed as a smaller size fraction.

\section{Pease Bay}

It was from the Pease Bay section (Fig. 1) that a ?Remigolepis specimen was described by Andrews (1974). This had been collected by Sir Frederick Stewart in 1957 from a fallen block of 'ORS' lithology and was only questionably assigned to the genus. However, reinvestigation in the field against the locality details given by Stewart (in Andrews 1974) and the rock description of Andrews (1974, p. 311) ...the sandstone matrix is of very irregular texture and colour, with lumps of dark calcareous matter and small grey-green clay galls. It had probably fallen from a similar bed of cornstone in the cliff above, lying about $6 \mathrm{~m}$ below the top of the Cornstone Group from a clay gall sandstone... gives a fairly obvious level from which the specimen originated. We have also had the specimen re-evaluated from the illustrations and it can be described confidently as Remigolepis (Ritchie pers. comm. 2016). The presence of this specimen was noted by Westoll (1977) and it was speculated that it might prove significant for dating the Remigolepis Series in East Greenland. We will now show that the converse is in fact the case. Following the work of Blom et al. (2005) it is now possible to match (Fig. 4) the exact range of Remigolepis against both the lithostratigraphy and the palynological record, all from East Greenland. These occurrences of Remigolepis spp. are from within the Aina Dal to Britta Dal Formations. Importantly the spore Retispora lepidophyta has its first occurrence in the upper Britta Dal Formation with an inception just $10 \mathrm{~m}$ above Acanthostega from the in situ locality on Stensiö Bjerg. Retispora lepidophyta has a globally restricted distribution to the latest Famennian (Streel 2009; Streel \& Marshall 2006) which means that in East Greenland Remigolepis becomes extinct in the early latest Famennian. Extending this correlation to the UK shows that the uppermost ORS in Pease Bay is within the age range of mid-early latest Famennian. The palynological assemblages in the Ballagan Formation from Pease Bay (Clayton 1971) contain many specimens of Claytonispora distincta. Our data from two long Ballagan Formation sections (e.g. Burnmouth, Fig. 5) shows that $C$. distincta is restricted to the lowest $140 \mathrm{~m}$ of the Ballagan Formation. Hence, the Pease Bay Ballagan Formation is also from the lower part of the formation. The Ballagan Formation section at Pease Bay (Grieg 1988) appears to be thin but is, in fact, truncated by the Cove Fault with the Pu zone absent and the overlying TC spore zone occurring in the shale overlying the Kip Carle Sandstone. This means that the missing latest Famennian ( $2 \mathrm{My}$ ) should be present within the super mature stage 6 calcrete (Eastern Hole Conglomerate) present in Pease Bay (Andrews et al. 1991; Wright et al. 1993) and other upper Kinnesswood Formation sections (Glenrothes Borehole, Wright et al. 1993; Carham Limestone, Carruthers et al. 1932). The terrestrial palaeoclimate record from the Famennian in East Greenland (Astin et al. 2010) shows a very arid interval through the mid and late Famennian Britta Dal Formation. But the latest Famennian Stensiö Bjerg Formation had greater seasonality with wetter wet times and drier dry times as shown by the presence of lakes and calcretes rather than a stack of vertisols. This 
can be attributed to the latest Famennian glaciations (as reviewed in Lakin et al. 2016) that in the Borders showed the cumulative far-field response of a composited supermature calcrete representing a significant arid hiatus in excess of several hundred thousand years per calcrete horizon (Wright et al. 1993). Hence the top of the Kinnesswood Formation at Pease Bay is placed at the top of the range of Remigolepis to reflect a view that the most likely condensed interval would be the latest Famennian glacial cycles.

A further stratigraphically important fish known from the Pease Bay area (Miles 1968) is Grossilepis brandi from Hazeldean Burn, close to Siccar Point. It is related to other Grossilepis species which in the Baltic (Esin et al. 2000) are found in the Frasnian. This is the only evidence for the age of the base of the Upper 'ORS' Greenheugh Sandstone Formation (Fig. 2) in Scotland and implies that it lies within the Frasnian.

\section{Burnmouth}

The longest and most complete surface section of the Ballagan Formation (Fig. 5) is in the intertidal zone at Burnmouth where it totals some $520 \mathrm{~m}$ of near vertical strata (Bennett et al. 2016; Kearsey et al. 2016) from an apparently conformable contact with the Kinnesswood Formation to a truncated top beneath the Fell Sandstone. This has previously been ascribed a CM late Tournaisian spore zone age (Scott et al. 1984). During the initial discovery of tetrapods from the Burnmouth section (Smithson et al. 2012) we recovered a palynological residue from a tetrapod bed at the base of the section. This contained a sparse simple assemblage lacking Schopfites claviger, the spore which defines the base of the CM zone. Dominant in the assemblage were specimens of Retusotriletes incohatus, Plicatispora scolecophora (Fig. 7) which enabled us (Smithson et al. 2012) to place it within the VI spore assemblage of earliest Carboniferous age. The lithologies in the underlying Kinnesswood Formation are dominantly red and yellow sandstones with no preserved organic matter and so it proved impossible to find palynomorphs. The only fossils from this location are the rare fish fragments collected by Stan Wood that include holoptychiid scales. As part of the TW:eed project we undertook detailed logging of the Ballagan Formation at Burnmouth with particular attention to the base of the formation. The recognition that there were earliest Tornaisian VI zone palynomorphs at the base of the formation and reported late Tournaisian CM spores (Scott et al. 1984) at a height of $70 \mathrm{~m}$ in the formation implied that a significant fault or hiatus should be present. However, detailed investigation, UAV (drone survey, Lidar and logging has shown no evidence for any fault or hiatus along the line of our logged section. Minor faults were identified but these do not cut the section. The critical parts of the section were studied twice a year during low spring tide. These sections might appear entirely covered by algal growth but at the lowest levels that are only exposed during the spring tides the dominant cover is the brown seaweed Laminaria. The upper blades of these weeds can be turned to reveal the underlying holdfast and stipe. These holdfasts are spaced apart with, in contrast to higher levels of the shore, little intervening encrusting cover such that rock and particularly the bedding becomes visible. This reveals that the section is entirely contiguous. It could still be speculated that there were significant hiatuses present within palaeosols similar to the stage 6 calcrete at Pease Bay. However, there is now a detailed published record of the palaeosols from the Burnmouth section (Kearsey et al. 2016) in addition to the much better record from the comparative section in the Norham West Mains Farm borehole. This shows that there are no identifiable palaeosols present at Burnmouth from the base of the Ballagan Formation to the inception of Schopfites delicatus. Instead, the last bed of the Kinesswood Formation (Fig. 6) is directly overlain by a cementstone and fine sandstones with wave ripples. This indicates that there was no significant erosional unconformity at the base of the Ballagan Formation. Some 64 palaeosols have been identified higher in the section but these are vertisols, 
inceptisols, gleyed inceptisols and entisols. None of these palaeosols have calcrete levels present within them and there are no thick higher stage calcretes. These Ballagan palaeosols only represent hiatuses of 10 to $1000 \mathrm{yrs}$. The palaeosol types that are present formed relatively rapidly, and are evenly distributed in both their individual thickness and spacing throughout the formation. This shows that there is no possibility of a hidden hiatus or hiatuses within the section. In addition to the detailed logging there was extensive focused sampling for palynomorphs from the Ballagan Formation at Burnmouth. These were located along the logged section line using differential GPS with an accuracy of $2 \mathrm{~cm}$. From this sample set we processed some 275 samples for palynology (plus a further 82 rejected on lab inspection) of which 107 (39\%) were productive. Compared to the spore recovery from the correlative section in the Norham West Mains Farm borehole (Fig. 1) the spore recovery is disappointing. Within the near vertical section it proved very difficult to sample adequately the very thin mudstone laminae that are present on partings between the sandstones. These are readily altered along bedding plane surfaces and are often the preferential horizon for the extant local burrowing infauna. The best recovery was at the base of the section and through the interval to the south side of the bay. Many of the samples contain organic matter although this is often dominated by black phytoclasts with relict spores, either the result of recent alteration or immediate post-depositional Carboniferous weathering. In general, the palynological assemblages are somewhat simple and dominated by Schopfites delicatus and Auroraspora macra together with simple retusoid spores. Clearly there is an element of the Ballagan Formation flora (Neves \& Belt 1971; Van der Zwan et al. 1985; Stephenson et al. 2002, 2004a) that was dry adapted flora with a restricted spore assemblage. But our intensive sampling programme revealed the existence of rarer samples that contained a more diverse microflora that included key taxa used in international correlation. Fig. 5 shows the sequence of inceptions of these key taxa for the lower part of the Burnmouth section. Inceptions include Cristatisporites hibernicus, $(32.75 \mathrm{~m})$, Anaplanisporites baccatus $(50.0 \mathrm{~m})$ ), Claytonispora distincta (70.75 m; formerly Umbonatisporites or Dibolisporites distinctus), Grandispora upensis (96.25 m) and Neoraistrickia cymosa $(98.55 \mathrm{~m})$ with a similar sequence of inceptions as found in both southern Ireland (Higgs et al. 1988), SW Britain (Hennessy \& Higgs 1999), South Wales (McNestry 1988) and Belgium (Higgs et al. 1992). This enables us to recognise VI and HD spore zones. Significantly, there is the inception of Schopfites as Schopfites delicatus at $33.75 \mathrm{~m}$ within these ranges. Identification of this as Schopfites claviger would lead to an identification of the base of the CM zone (i.e. the late Tournaisian). But, this gives a conflicting result as this late Tournaisian marker would be either considerably below its normal range or that the inceptions of the $\mathrm{VI}$ and HD zone spores were considerably delayed. However, these early Tournaisian spores still appeared in the correct sequence as the section transitions from the fluvial Kinnesswood Formation to the coastal matrix of Ballagan environments. The answer is that the spore reported as Schopfites claviger through much of the Ballagan Formation is the species with much smaller sculpture known as Schopfites delicatus and, as such, occurs below the range of S. claviger (Higgs 1975; Higgs et al. 1988). This distinction was first discussed by Keegan (1981) and then reiterated in Higgs et al. (1988) although some authors regard $S$. delicatus as a variant of S. claviger (Welsh 1979). In Burnmouth S. delicatus is only replaced significantly up section by forms that approach $S$. claviger as defined by the mean size of sculpture (e.g. Fig. 8; $257.9 \mathrm{~m}$ ). Hence, it would appear that $S$. claviger has been generally used within the Ballagan Formation for $S$. delicatus with its smaller more gracile sculpture and before the significance of this distinction was established. Realistically this distinction is quite difficult to apply as any method that requires averages of micron scale measurement of spore sculpture does not fit easily into a zonation that is otherwise based on inceptions of distinctive species. The implication for time correlation within the Ballagan Formation is that many sections that have been attributed to the $\mathrm{CM}$ zone and, hence, a late Tournaisian age on the basis of Schopfites claviger but are, in fact, somewhat older. Another spore present is Anaplanisporites baccatus that has an inception at $50 \mathrm{~m}$ just above 
that of Schopfites delicatus. It is the in situ microspore of the creeping lycopod Oxroadia (Bateman 1992; Stevens et al. 2010) that is very common in the Ballagan Formation and appears adapted to less stable environments. In Ireland $A$. baccatus is not present on the clastic margin but has an inception in the higher part of the PC zone.

In the Western European spore zonation, the zones above HD are defined on the inception of various species of Spelaeotriletes and Raistrickia. However, these species are not abundant in the Borders, occurring only sporadically. At Burnmouth the VI spore zone can be identified at the base of the Ballagan Formation with the Pu zone occurring in other sections (Millward et al. 2018) at about the level of the Fell Sandstone Formation which shows that a complete Tournaisian section is present. However, within this section Spelaeotriletes is never abundant. This contrasts with both southern Ireland (Higgs et al. 1988) and the Bristol area of England (Hennessy \& Higgs 1999) where they can make up $10 \%$ of the assemblage in a marginal shelf environment and are sufficiently diverse to define an evolutionary lineage (Brittain \& Higgs 2007). They are similarly abundant in the fully terrestrial Tournaisian in East Greenland (Vigran et al. 1999) and Nova Scotia (Utting et al. 1989) where they can comprise $90 \%$ of the palynological assemblage. Clearly, there is an element of environmental control on the abundance of these taxa in the Ballagan Formation. This focuses attention on the validity of single inceptions to define zones as key taxa increasingly appear to occur with different sequences of first appearance when investigated from different areas. For example, $C$. distincta occurs together with Retispora lepidophyta in Devonian rocks in western Canada (McGregor and Utting in Utting et al. 1989, p. 130). Other exception to ranges between the UK, Ireland and Eastern Europe are detailed in Clayton \& Turnau (1990).

The next significant inception as regards palynological zonation (Fig. 5) is that of Prolycospora claytonii with an inception at $189.9 \mathrm{~m}$ and with a local acme (48\%) at $257.9 \mathrm{~m}$. With only a few records in Western Europe (Clayton \& Turnau 1990) Prolycospora claytonii has not been regarded as important for the palynological subdivision in the British Isles. It is distinctly different from Prolycospora rugulosa which has been recognised in Western Europe but is tripapillate (Higgs et al. 1988; Butterworth \& Spinner 1967). Prolycospora claytonii was a major component in palynological assemblages from Eastern Europe (Turnau 1978; Avchimovitch \& Turnau 1994), primarily Poland and Belarus, and forms the basis for an alternative zonation. More importantly the zonation from Poland is tied to the international conodont scale (Matyja et al. 2000) with both palynomorphs, conodonts and ostracods in the same sections. This contrasts with the limited conodont information available from Ireland that produces a local zonation based largely on shallow water and endemic forms. The inception of Prolycospora at Burnmouth is used to place the $\mathrm{Cl} 1$ zone base at $189.9 \mathrm{~m}$. This is somewhat below the base of the late Tournaisian in terms of the established Tournaisian conodont zone. Applying the Polish zonation to Burnmouth also enables other approximate ties to be made to the conodont zonation and giving some element of precision for correlation into the marine sequences. In the Polish zonation (Matyja et al. 2000) spore zone Ma1 is placed at the inception of Cristatisporites hibernicus with Ma2 and HD both coincident with the base of Claytonispora distincta. This places the base of the sandbergi conodont zone just below the inception of $\mathrm{Ma} 2 / \mathrm{HD}$ and is also the base of the Alum Shale (Hartenfels et al. 2016). This is an episode of marine warming and stratification coincident with the Miller Diamictite/Soutklouf Shale in South Africa (see review in Lakin et al. 2016) and the ending of a Tournaisian glaciation. In Western Europe this is marked by an increase in spore diversity with the inception of new species. The next conodont zone that can be placed is the typicus zone just above the base of spore zone $\mathrm{Cl} 1$.

\section{Whiteadder Water, Preston}


This re-zonation of the Ballagan Formation from Burnmouth with the VI spore zone at its base followed by the entire Tournaisian causes an immediate problem as, by implication, the underlying Kinnesswood Formation has to be mostly Devonian in age. This is supported by the presence of the Famennian fish Remigolepis at Pease Bay. However, to resolve this issue what is required is direct, unqualified and independent age evidence from the Kinnesswood Formation. There have been continuing attempts to find palynomorphs in the Kinnesswood and underlying 'Upper 'ORS' formations but none have succeeded. The recognition in 1999 of the Devonian-Carboniferous boundary in terrestrial sections in East Greenland gave a sedimentological motif of a distinctive prolonged climatically wet interval (Marshall et al. 1999) that hopefully could be identified within the Scottish sections. But despite the first author searching across Scotland no similar motif could be identified and no spores have been found. There has been more success in the offshore hydrocarbon wells with a number of records of Retispora lepidophyta. But these are all based on drill cuttings from rather old wells in sand-rich sequences and have not yet enabled a clear definition of the boundary with respect to the lithostratigraphy.

It was from the Whiteadder Water at Preston that the first ever palynological assemblage from upper 'ORS' strata underlying the Ballagan Formation was discovered in a section where thin mudstones are interbedded with volcaniclastic rocks from the Kelso Volcanic Formation. This palynological assemblage is regarded as very significant and together with the re-zonation of the Ballagan Formation and the Remigolepis specimen from Pease Bay provides a coherent narrative. To place this in context it is the first ever palynological assemblages from the onshore Upper Old Red Sandstone from Northern Britain and, as such, is reported here before being fully documented elsewhere. Diverse and well preserved Famennian palynological assemblages are rare in Western Europe and this new assemblage contains many examples of grapnel-tipped spores that are otherwise poorly described.

The main elements of the assemblage are in Table 2 and illustrated on Fig. 7 with ranges against the established spore zonation shown on Fig. 9. The assemblage contains a diversity of the three main genera of grapnel-tipped spores: Ancyrospora, Hystricosporites and Nikitinsporites. The latter is only present as an isolated spine from a megaspore. All three of these genera become extinct at the Devonian-Carboniferous boundary. Other species present within the assemblage that also terminate at the Devonian-Carboniferous boundary include Diducites versabilis, Rugospora radiata and Vallatisporites pusillites. Also present is the megaspore Tergobulasporites immensus that is Famennian in age (Turnau 2002) and reportedly became extinct before the first appearance of Retispora lepidophyta. Retispora macroreticulata is present which is again Famennian in distribution but becomes extinct before the Devonian-Carboniferous boundary and at the base of the LL (Maziane et al. 1999) or LN (Higgs et al. 1988) spore zones. Also present are rare specimens of Retispora lepidophyta which has an inception in the latest Famennian and also became extinct at the DevonianCarboniferous boundary. There are not enough specimens of $R$. lepidophyta to acquire meaningful data on its diameter but those present are small in size (Fig. $711,52 \mu \mathrm{m}$ diameter) and close to $R$. lepidophyta minor in diameter which characterizes the base of the species range (Maziane et al. 2002). This places it in the LL spore zone or younger accepting the presence of $T$. immensus. Absent from the assemblage are Indotriradites explanatus and Verrucosisporites nitidus. These define the bases of the younger LE and LN spore zones respectively (but see Prestianni et al. 2016 for further discussion of the $L N$ zone) and implies a position in the LL zone of early latest Famennian age. So, the assemblage is unequivocally Famennian and more specifically early latest Famennian in age.

Identification of an LL palynological assemblage is very significant as it enables the key stratigraphic markers in the uppermost Kinnesswood Formation to be time correlated in the section at Pease Bay. The Whiteadder Water samples are interbedded with volcaniclastic debris and this also demonstrates 
that the Kelso Lavas were, at least in part, from the LL spore zone. However, this section on the Whiteadder is of little further value for establishing stratigraphical correlations as the beds are at a steep angle and lie within a fault zone. A more tractable although now poorly exposed section is 18 $\mathrm{km}$ to the south at Carham and was described by Carruthers et al. (1932). The section (Fig. 10) includes a very significant Stage 6 dolomitic calcrete which includes a $60 \mathrm{~cm}$ thick central band of pink chert, i.e. a silcrete. It is reported as up to $6 \mathrm{~m}$ in thickness (normally $3 \mathrm{~m}$ ) and is present above the Kelso Lavas from which it is separated by a thin sedimentary intercalation. The calcrete has been extensively exploited for lime production and was well exposed at the time of the primary survey (Clough 1888). Above the calcrete there is a poorly exposed sequence of Ballagan Formation that was formerly quarried (c. 1860) in the Shidlaw Tile Works (Carruthers et al. 1932). All these units were previously well exposed with stratigraphical continuity in cuttings along the then operational North Eastern Railway. These stratigraphic relationships have been re-examined by the current authors and are as described by Carruthers et al., (1932). The calcrete is a very significant stratigraphic marker in the Borders and Midland Valley of Scotland with the occurrence of a single Stage 6 calcrete in the Glenrothes borehole (Wright et al. 1993), Pease Bay (Andrews \& Nabi 1998) and South Ayrshire (Burgess 1961). Wright et al. (1993) estimate that this calcrete represents a time gap of several hundred thousand years or longer. The calcrete is used as the correlation tie between Carham and Pease Bay with the further tie being between the Kelso Lavas from Preston to Carham. These lithostratigraphic correlations demonstrate that the time gap represented by the calcrete lies above the early Latest Famennian and below the start of the Ballagan Formation that approximates the Devonian-Carboniferous boundary. In the Borders the development of these calcretes represents the complex interplay between local uplift associated with volcanic doming (Millward et al. 2018) and latest Famennian glacial drawdown. In East Greenland this time interval is represented by the Stensiö Bjerg Formation (Astin et al., 2010) and equivalent to the latest Devonian Gondwana glaciation(s) that is represent in the southern hemisphere arid zone by an interval of sustained aridity.

Leeder (1976) documented a further series of calcrete localities in the southern part of the Border Basin. Importantly these occur as a pair of calcretes that are below the Birrenswark Volcanic Formation which is the lateral correlative of the Kelso Volcanic Formation. If these can be dated palynologically they have the potential to provide further links to the Famennian palaeoclimate record. There are further thick calcretes in the western part of the Midland Valley including two on Arran (Young \& Caldwell 2009; Jutras et al. 2011) which have a complex age relationship that now requires reinterpretation following reassignment of the Kinnesswood Formation to the Famennian.

\section{Conclusions}

This review of existing stratigraphical information coupled with new palynological data (Fig. 11) shows that:

The Upper Old Red Sandstone Kinnesswood Formation in Scotland is not Early Carboniferous in age as previously inferred but unequivocally Late Devonian in age and more specifically in part Famennian.

The base of the Ballagan Formation approximates to the Devonian-Carboniferous boundary with the oldest Tournaisian VI spore zone present at the base of the succession at Burnmouth.

The Ballagan Formation does not represent only the $\mathrm{CM}$ spore zone of late Tournaisian age but includes the entire Tournaisian with at least the VI, HD, Cl 1 and CM (ss) spore zones present. 
Calcretes can be correlated from key sections at Pease Bay and Carham that enables the Pease Bay calcrete to be recognised as latest Devonian in age.

Records of typical Devonian fish such as Holoptychius and Bothriolepis characterise the Kinnesswood Formation and were regarded as range extensions into the Carboniferous. These are now shown to be Devonian in age further emphasising the magnitude of the terrestrial Devonian-Carboniferous boundary mass extinction. They can be used as zone fossils to identify rock successions as Devonian in age.

This means that all the Romer's Gap tetrapods and arthropods found in the Ballagan Formation are not from a brief upper interval of late Tournaisian age but from the entirety of the $12 \mathrm{My}$ of Tournaisian time. This has significant implications for the construction of phylogenies for the early tetrapods. In particular, it brings the lower Ballagan Formation tetrapods close in time to the very different aquatic forms (Acanthostega and Ichthyostega) from East Greenland. This redistribution of Ballagan tetrapods through the entirety of the Tournaisian has filled the crucial lower part of Romer's Gap.

\section{Acknowledgements}

This research formed part of the TW:eed Project (Tetrapod World: early evolution and diversification), led by Jenny Clack (University Museum of Zoology, Cambridge) and funded by NERC consortium grants to the University of Southampton (NE/J021091/1), British Geological Survey (NEJ021067/1), University of Leicester (NE/J020729/1) and University of Cambridge (NE/J022713/1). Mike Browne, Tim Kearsey and Dave Millward publish with the permission of the Executive Director, BGS (NERC). Shir Akbari (Southampton) processed the palynological samples. Alex Ritchie and Vincent Dupret reinvestigated the Remigolepis from Pease Bay. Sasha Ivanov provided useful information on the synonymies of Grossilepis. Peter Osterloff (Shell) facilitated access to cuttings samples from offshore wells that cross the D-C boundary. Jenny Clack, our TW:eed Project Principal Investigator, given the nature of this published volume, graciously declined her right to be a co-author on this contribution. We acknowledge her contributions to the project from its inception and particularly her understanding of the importance of a new look at the low diversity Ballagan Formation spore assemblages. They proved to be anything but boring. 


\section{References}

Andrew, C.J. \& Poustie, A. 1986. Syndiagenetic or epigenetic mineralisation - the evidence from Tatestown zinc-lead prospect, Co. Meath. In Andrew, C.J., Crowe, R.W.A., Finlay, S., Pennel, W.M., Pyne, J.F. (eds) Geology and Genesis of Mineral Deposits in Ireland, IAEG 281-296.

Andrews, J.E. \& Nabi, G. 1998. Palaeoclimatic significance of calcretes in the Dinantian of the Cocksburnpath Outlier (East Lothian-North Berwickshire). Scottish Journal of Geology 34, 153-164.

Andrews, J.E., Turner, M.S., Nabi, G. \& Spiro, B. 1991. The anatomy of an early Dinantian terraced floodplain: palaeo-environment and early diagenesis. Sedimentology 38, 271-287.

Andrews, S.M. 1974. A possible occurrence of Remigolepis in the topmost Old Red Sandstone of Berwickshire. Scottish Journal of Geology 14, 311-315.

Anon. 1939. Forthcoming Events. Nature 144, 453-454.

Astin, T.R., Marshall, J.E.A., Blom, H. \& Berry, C.M. 2010. The sedimentary environment of the Late Devonian East Greenland tetrapods. In Vecoli, M., Clement, G. \& Meyer-Berthaud, B. (eds) The Terrestrialization Process: Modelling Complex Interactions at the Biosphere-Geosphere Interface.

Special Publication Geological Society of London 339, 93-109.

Avchimovitch, V.I. \& Turnau, E. 1994. The Lower Carboniferous Prolycospora claytonii Zone of Western Pomerania and its equivalents in Belorussia and Northwestern Europe. Annales Societatis Geologorum Poloniae 63, 249-263.

Bateman, R.M. 1992. Morphometric reconstruction, palaeobiology and phylogeny of Oxroadia gracilis Alvin emend. and $O$. conferta sp. nov.: anatomically-preserved rhizomorphic lycopsids from the Dinantian of Oxroad Bay, SE Scotland. Palaeontographica Abt. B 228, 29-103.

Bennett, C.E., Kearsey, T.I., Davies, S.J., Millward, D., Clack, J.A., Smithson, T.R. \& Marshall, J.E.A. 2016. Early Mississippian sandy siltstones preserve rare vertebrate fossils in seasonal flooding episodes. Sedimentology 63, 1677-1700.

Blom, H., Clack, J. A. \& Ahlberg, P. E. 2005. Localities, distribution and stratigraphical context of the Late Devonian tetrapods of East Greenland. Meddelelser om Grønland Geoscience 43, 1-50.

Brittain, J.M. \& Higgs, K.T. 2007. The early Carboniferous Spelaeotriletes balteatus - S. pretiosus miospore complex: defining the base of the Spelaeotriletes pretiosus - Raistrickia clavata (PC) miospore biozone. Communicações Geológicas 94, 109-123.

Browne, M.A.E., Smith, R.A., \& Aitken, A.M. 2002. Stratigraphical framework for the Devonian (ORS) rocks of Scotland south of a line from Fort William to Aberdeen. BGS Research Report RR/01/04.

Burgess, I.C. 1961. Fossil soils of the Upper Old Red Sandstone of south Ayrshire. Transactions of the Geological Society of Glasgow 24, 138-153.

Bütler, 1961. Devonian deposits of Central East Greenland. In Raasch, G.O. (ed) Geology of the Arctic Toronto, Canada, University of Toronto Press 1, 188-196.

Butterworth, M.A. \& Spinner, E.G. 1967. Lower Carboniferous spores from north-west England. Palaeontology 10, 1-24.

Carruthers, R.G., Burnett, G.A. \& Anderson, W. 1932. The Geology of the Cheviot Hills. Memoirs of the Geological Survey England and Wales. Explanations of Sheets 3 \& 5, HMSO, London.

Clack, J.A., Bennett, C.E., Carpenter, D.K., Davies, S.J., Fraser, N.C., Kearsey, T.I., Marshall, J.E.A., Millward, D., Otoo, B.K.A., Reeves, E.J., Ross, A.J., Ruta, M., Smithson, K.Z., Smithson, T.R., \& Walsh, S.A. 2016. Phylogenetic and environmental context of a Tournaisian tetrapod fauna. Nature, Ecology \& Evolution, 1, DOI: 10.1038/s41559-016-0002

Clayton, G. \& Turnau, E. 1990. Correlation of the Tournaisian miospore zonations of Poland and the British Isles. Annales Societatis Geologorum Poloniae 60 45-58.

Clayton, G. 1971. A Lower Carboniferous miospore assemblage from the Calciferous Sandstone Measures of Cocksburnpath region of eastern Scotland. Pollen et Spores 12, 577-600.

Clough, C.T. 1888. The Geology of the Cheviot Hills (English side). Memoirs of the Geological Survey.

Dineley, D. \& Metcalf, S. 1999. Hawks Heugh, Fossil Fishes of Great Britain, Geological Conservation Review Series, No. 16, Joint Nature Conservation Committee, Peterborough, 675 pages. 
Esin, D., Ginter, M., Ivanov, A., Lebedev, O., Luksevics, E., Avkhimovitch, V., Golubtsov, V. \& Petukhova, L. 2000. Vertebrate correlation of the Upper Devonian and Lower Carboniferous on the East European Platform. Courier Forschungsinstitut Senckenberg 223, 341-349.

Eyles, V.A., Simpson, J.B. \& MacGregor, A.G. 1949. Geology of Central Ayrshire. Memoirs of the Geological Survey, Scotland. Explanation of one-inch sheet 14, Second Edition, reprinted 1980.

Friend, P.F. Williams, B.P. 1978. Devonian of Scotland, the Welsh Borderland and South Wales. International Symposium on the Devonian System. Palaeontological Association Devonian System, Bristol, 1978 1-106.

Grieg, D.C. 1988. Geology of the Eyemouth District. Memoir for the 1:50 000 geological sheet 34 (Scotland). 1-78.

Hance, L., Poty, E. \& Devuyst, F-X. 2006. Tournaisian. Geological Belgica 9, 47-53.

Hartenfels, S., Hartkopf-Fröder, C., Herbig, H.-G., Becker, R.T. \& Esteban Lopez, S. 2016. Middle Famennian to Viséan stratigraphy at Riescheid (Herzkamp Syncline, Rhenish Massif). Münstersche Forschungen zur Geologie und Paläontologie 108, 102-125.

Hartz, E.H., Torsvik, T.H. \& Andresen, A. 1997. Carboniferous age for the East Greenland "Devonian" basin: Palaeomagnetic and isotopic constraints on age, stratigraphy, and plate reconstructions. Geology 25, 675-678.

Hartz, E.H., Torsvik, T.H. \& Andresen, A., 1998, Carboniferous age for the East Greenland "Devonian" basin: Paleomagnetic and isotopic constraints on age, stratigraphy, and plate reconstructions: Reply: Geology 26, 285-286.

Hennessy, D. \& Higgs, K.T. 1999. Palynological zonation of the Late Devonian and Early Carboniferous of the Avon Gorge, southwest England. Bollettino della Società Paleontologica Italiana 38, 177-186.

Higgins, A.C. \& Varker, W.J. 1982. Lower Carboniferous conodont faunas from Ravenstonedale, Cumbria. Palaeontology 25, 145-166.

Higgs, K., 1975, Upper Devonian and Lower Carboniferous miospore assemblages from Hook Head, County Wexford, Ireland, Micropalaeontology 21, 393-419.

Higgs, K., Clayton, G. \& Keegan, J.B. 1988. Stratigraphic and Systematic Palynology of the Tournaisian Rocks of Ireland. The Geological Survey of Ireland, Special Paper Number 7, 1-93

Higgs, K.T., Dreesen, R., Dusar, M. \& Streel, M. 1992 Palynostratigraphy of the Tournaisian (Hastarian) rocks in the Namur Synclinorium, West Flanders, Belgium. Review of Palaeobotany and Palynology 72, 149-158.

Holliday, D.W., Neves, R. \& Owens, B. 1979. Stratigraphy and palynology of early Dinantian (Carboniferous) strata in shallow boreholes near Ravenstonedale, Cumbria. Proceedings of the Yorkshire Geological Society 42, 343-356.

Jarvik, E. 1948, Note on the Upper Devonian Vertebrate Fauna of East Greenland and on the age of the Ichthyostegid Stegocephalians. Arkiv för Zoologi 41, (13) 1-8.

Jarvik, E. 1950. Note on Middle Devonian crossopterygians from the eastern part of Gauss Halvö, East Greenland. Meddeleleser om Grønland 149 (6) 1-20.

Jarvik, E. 1961, Devonian vertebrates. In Raasch, G.O. (ed) Geology of the Arctic Toronto, Canada, University of Toronto Press 1, 197-204.

Jarvik, E. 1996, The Devonian tetrapod Ichthyostega. Fossils and Strata 40, 1-213.

Johnson, G.A.L. \& Marshall, A.E. 1971. Tournaisian beds in Ravenstonedale, Westmorland. Proceedings of the Yorkshire Geological Society 38, 261-280.

Jongmans, W.J. \& Gothan, W. 1937. Betrachtungen über die Ergebnisse des zweiten Kongresses für Karbonstratigraphie. Deuxième Congrès International de Stratigraphie et de Gèologie du Carbonifère, Herleen, 1935, Compte Rendu 1, 1-40.

Jutras, P., Young, G.M. \& Caldwell, W.G.E. 2011. Reinterpretation of James Hutton's historic discovery on the Isle of Arran as a double unconformity masked by a phreatic calcrete hardpan. Geology 39, 147-150.

Kearsey, T.I., Bennett, C.E., Millward, D., Davies, S.J., Gowing, C.J.B., Kemp, S.J., Leng, M.J., Marshall, J.E.A., Browne, M.A.E. 2016. The terrestrial landscapes of tetrapod evolution in earliest 
Carboniferous seasonal wetlands of SE Scotland Palaeogeography, Palaeoclimatology, Palaeoecology 457, 52-69.

Keegan, J.B. 1981. Palynological correlation of the Upper Devonian and Lower Carboniferous in central Ireland. Review of Palaeobotany and Palynology 19, 545-573.

Lakin, J.A., Marshall, J.E.A., Troth, I., \& Harding, I.C. 2016. Greenhouse to icehouse: a biostratigraphic review of latest Devonian-Mississippian glaciations and their global effects. In Becker, R. T., Königshof, P. \& Brett, C. E. (eds) Devonian Climate, Sea Level and Evolutionary Events. Geological Society, London, Special Publication 423, 439-464.

Leeder, M.R. 1976. Palaeogeographic significance of pedogenic carbonates in the topmost Upper Old Red Sandstone of the Scottish border basin. Geological Journal 11, 21-28.

Marshall, J.E.A., Astin, T.R. \& Clack, J.A. 1999. The East Greenland tetrapods are Devonian in age. Geology 27, 637-640.

Matyja, H., Turnau, E. \& Żbikowska, B. 2000. Lower Carboniferous (Mississippian) stratigraphy of Northwestern Poland: conodont, miospore and ostracod zones compared. Annales Societatis Geologorum Poloniae 70, 193-217.

Maziane, N., Higgs, K.T. \& Streel, M. 1999. Revision of the late Famennian miospore zonation scheme in eastern Belgium Journal of Micropalaeontology 18, 17-25.

Maziane, N., Higgs, K.T. \& Streel, M. 2002. Biometry and paleoenvironment of Retispore lepidophyta (Kedo) Playford 1976 and associated miospores in the latest Famennian nearshore marine facies, eastern Ardenne (Belgium). Review of Palaeobotany and Palynology 118, 211-226.

McNestry, A. 1988. The palynostratigraphy of two uppermost Devonian-Lower Carboniferous borehole sections in South Wales. Review of Palaeobotany and Palynology 56, 69-87.

Miles, R.S. 1968. The Old Red Sandstone Antiarchs of Scotland, Family Bothriolepididae, Palaeontographical Society Monographs 122, (522), 1-130.

Millward, D., Davies, S. J., Brand, P. J. Browne, M.A. E., Bennett, C. E., Kearsey, T. I., Sherwin, J. E. \& Marshall, J. E. A. 2018. Palaeogeography of tropical seasonal coastal wetlands in northern Britain during the early Mississippian Romer's Gap. Earth \& Environmental Transactions Royal Society Edinburgh. 1-22. doi: 10.1017/S1755691018000737

Neves, R. \& Belt, E.S. 1971. Some observations on Namurian and Viséan spores from Nova Scotia, Britain and Northern Spain Sixième Congrès International de Stratigraphie et de Géologie du Carbonifere $\left(6^{\text {th }}\right)$, Sheffield, England, 1967 (v),1233-1249.

Neves, R., Gueinn, K.J., Clayton, G., loannides, N.S., Neville, R.S.W. \& Kruszewska, K. 1973. Palynological correlations within the Lower Carboniferous of Scotland and Northern England. Transaction of the Royal Society of Edinburgh 69, 23-70.

Neves, R. \& loannides, N. 1974. Palynology of the Spilmersford Borehole. Bulletin of the Geological Survey of Great Britain 45, 73-97.

Nicholson J. \& Friend P. F. 1976. Devonian sediments of East Greenland. V. The central sequence, Kap Graah Group and Mount Celsius Supergroup. Meddelelser om Grønland 206 (5), 1-117.

Olsen, H., \& Larsen, P.-H. 1993. Lithostratigraphy of the continental Devonian sediments in North-East Greenland. Bulletin of the Grønlands Geologiske Undersøgelse 165, 1-108.

Patterson, C. \& Fortey, R.A. 1999. Thomas Stanley Westoll, 3 July 1912-19 September 1995. Biographical Memoirs of the Fellows of the Royal Society 1999 45, 531-546.

Playford, G. \& Melo, J.H.G. 2012. Miospore palynology and biostratigraphy of Mississippian strata of the Amazonas Basin, northern Brazil. AASP Contributions Series 47, 1-201.

Prestianni, C., Sautois, M. \& Denayer, J. 2016. Disrupted continental environments around the Devonian-Carboniferous Boundary: introduction of the tener event. Geologica Belgica 19, 135-145.

Read, W.A., Browne, M.A.E., Stephenson, D. \& Upton, B.G.J. 2002. Carboniferous, In Trewin, N.G. (ed) Geology of Scotland 251-299, The Geological Society, London.

Romer, A.S. 1945. Vertebrate Paleontology. University of Chicago Press, $2^{\text {nd }}$ Edition.

Sallan, L.C. \& Coates, M.I. 2010. End-Devonian extinction and a bottleneck in the early evolution of modern jawed vertebrates. PNAS 107, 10131-10135. 
Säve-Söderbergh, G. 1934. Further contributions to the Devonian stratigraphy of East Greenland. Meddeleleser om Grønland 96 (2), 1-74.

Schultze, H.-P. 2009. The international influence of the Stockholm School. Acta Zoologica 90, (Suppl. 1), 22-37,

Scott, A.C., Galtier, J. \& Clayton, G. 1984. Distribution of anatomically-preserved floras in the Lower Carboniferous in Western Europe. Transaction of the Royal Society of Edinburgh: Earth Sciences 75, 311-340.

Smithson, T.R., Wood, S.P., Marshall, J.E.A. \& Clack, J.A. 2012. Earliest Carboniferous tetrapod and arthropod faunas from Scotland populate Romer's Gap. PNAS 109, 4532-4537.

Stemmerik, L. \& Bendix-Almgreen, S. E., 1998, Carboniferous age for the East Greenland "Devonian" basin: Paleomagnetic and isotopic constraints on age, stratigraphy, and plate reconstructions: Comment. Geology 26, 284-285.

Stephenson, M., Williams, M., Monaghan, A., Arkley, S. \& Smith, 2002. Biostratigraphy and palaeoenvironments of the Ballagan Formation (lower Carboniferous) in Ayrshire, SW Scotland. Scottish Journal of Geology 38, 93-111.

Stephenson, M.H., Williams, M., Monaghan, A.A., Arkley, S. \& Smith, R.A. Dean, M., Brown, M.A.E. \& Leng, M. 2004a. Palynomorph and ostracod biostratigraphy palaeoenvironments of the Ballagan Formation, Midland Valley of Scotland, and elucidation of intra-Dinantian unconformities. Proceedings of the Yorkshire Geological Society 55, 131-143.

Stephenson, M.H., Williams, M., Leng, M.J. \& Monaghan, A.A. 2004b. Aquatic plant microfossils of probable non-vascular origin from the Ballagan Formation (Lower Carboniferous), Midland Valley, Scotland. Proceedings of the Yorkshire Geological Society 55, 145-148.

Stevens, L.G., Hilton, J., Rees, A.R., Rothwell, G.W. \& Bateman, R.M. 2010. Systematics, phylogenetics, and reproductive biology of Flemingites arcuatus sp. nov., an exceptionally preserved and partially reconstructed Carboniferous arborescent lycopsid. International Journal of Plant Sciences 171, 783-808.

Streel, M. \& Marshall, J.E.A. 2006. Devonian-Carboniferous boundary global correlations and their paleogeographic implications for assembly of Pangaea. In Wong, Th. E. (ed) Proceedings of the XVth International Congress on Carboniferous and Permian Stratigraphy. Utrecht, the Netherlands, 10-16 August 2003. Royal Netherlands Academy of Arts and Sciences, 481-496.

Streel, M. 2009. Upper Devonian miospore and conodont zone correlation in western Europe. In Königshof, P. (ed) Devonian Change: Case Studies in Palaeogeography and Palaeoecology, Special Publication of the Geological Society of London 314, 163-176.

Sullivan, H. 1968. A Tournaisian spore flora from the Cementstone Group of Ayrshire, Scotland. Palaeontology 11, 116-131.

Tomkieff, S.I. 1945. Petrology of the Carboniferous rocks of the Tweed Basin. Transactions of the Edinburgh Geological Society 14, 53-75.

Turnau, E. 1978. Spore zonation of uppermost Devonian and Lower Carboniferous deposits of Western Pomerania (N. Poland). Mededelingen rijks geologische dienst 30-1, 1-35.

Turnau, E. 2002. Two new Devonian spore genera from Euramerica and their stratigraphic and geographic distribution. Review of Palaeobotany and Palynology 118, 261-268.

Utting, J., Keppie, J.D. \& Giles, P.S. 1989. Palynology and stratigraphy of the Lower Carboniferous Horton Group, Nova Scotia. Geological Survey of Canada Bulletin 396, 117-143.

Van der Zwan, C.J., Boulter, M.C. \& Hubbard, R.N.L.B. 1985. Climatic change during the Lower Carboniferous in Euramerica, based on multivariate statistical analysis of palynological data. Palaeogeography, Palaeoclimatology, Palaeoecology 52, 1-20.

Varker, W.J. \& Higgins, A.C. 1979. Conodont evidence for the age of the Pinskey Gill Beds of Ravenstonedale, North-West England. Proceedings of the Yorkshire Geological Society 42, 357-369.

Varker, W.J. \& Sevastopulo, G.D. 1985. The Carboniferous System: Part 1 - Conodonts of the Dinantian Subsystem from Great Britain and Ireland. In Higgins, A.C. \& Austin, R.L. (eds) A Stratigraphical 
Index of Conodonts, 167-209. British Micropalaeontological Society Series, Ellis Horwood, Chichester.

Vigran, J.O., Stemmerik, L. \& Piasecki, S. 1999. Stratigraphy and depositional evolution of the uppermost Devonian-Carboniferous (Tournaisian-Westphalian) non-marine deposits in North-East Greenland. Palynology 23, 115-152.

Waters, C.N., Somerville, I.D., Jones, N.S., Cleal, C.J., Collinson, J.D., Waters, R.A., Besly, B.M., Dean, M.T., Stephenson, M.H., Davies, J.R., Freshney, E.C., Jackson, D.I., Mitchell, W.I., Powell, J.H., Barclay, W.J., Browne, M.A.E., Leveridge, B.E., Long S.L. \& McLean, D. 2011. A Revised correlation of the Carboniferous rocks in the British Isles. Geological Society of London, Special Report 26, 1186.

Waterston, C.D. 1965. Devonian. In Craig, G.Y., (ed) Geology of Scotland. Oliver \& Boyd.

Welsh, A. 1979. Stratigraphic palynology of the Early Dinantian strata in shallow boreholes at Ravenstonedale, Cumbria. The Sheffield University Geological Society Journal 7, 194-202.

Westoll, T.S. 1938. Ancestry of the tetrapods. Nature 141, 127-128.

Westoll, T. S. 1940 Contribution to discussion on the boundary between the Old Red Sandstone and the Carboniferous. Reports of the British Association for the Advancement of Science, no. 2, for 1939-40, 258.

Westoll, T.S. 1943. The origin of the tetrapods, Biological Reviews 18, 78-98.

Westoll, T.S. 1951. The vertebrate-bearing strata of Scotland: International Geological Congress, Reports, 18th Session, Great Britain, pt.11, 5-21.

Westoll, T.S. 1977. Northern Britain. In House, M.R., Richardson, J.B., Chaloner, W.G., Allen, J.R.L., Holland, C.H., Westoll, T.S. (eds) A correlation of the Devonian rocks in the British Isles. Geological Society of London, Special Report 7, 66-93.

Wright, V.P., Turner, M.S., Andrews, J.E. \& Spiro, B. 1993. Morphology and significance of super-mature calcretes from the Upper Old Red Sandstone of Scotland. Journal of the Geological Society 150, 871883.

Young, G.M. \& Caldwell, W.G.E. 2009. A new look at an old unconformity: field and geochemical data from James Hutton's original unconformity on the Isle of Arran, Scotland. Proceedings of the Geologists' Association 120, 65-75. 
Table 1

Spores from the Ballagan Formation at Burnmouth. Taxonomic citations not in the references will be found in Playford \& Melo (2012) or Higgs et al. (1988)

Anaplanisporites baccatus (Hoffmeister, Staplin \& Malloy) Smith \& Butterworth 1967

Claytonispora distincta (Clayton) Playford \& Melo 2012

Cristatisporites hibernicus (Higgs) Higgs 1996

Grandispora upensis (Kedo) Byvscheva 1980

Neoraistrickia cymosa Higgs, Clayton \& Keegan 1988

Plicatispora scolecophora (Neves \& loannides) Higgs, Clayton \& Keegan 1988

Prolycospora claytonii Turnau 1978

Retusotriletes incohatus Sullivan 1964

Schopfites claviger (Sullivan) Higgs, Clayton \& Keegan 1988

Schopfites delicatus Higgs 1975

Table 2

Spores from Kinnesswood Formation locality Whiteadder Water, Preston. Taxonomic citations not in the references will be found in Playford \& Melo (2012) or Higgs et al. (1988)

Ancyrospora spp.

Auroraspora asperella (Kedo) Van der Zwan 1980

Auroraspora solisorta Hoffmeister, Staplin \& Malloy 1955

Diducites versabilis (Kedo) Van Veen 1981

Endoculeosporites gradzinskii Turnau 1975

Gorgonispora crassa (Winslow) Higgs, Clayton \& Keegan 1988

Grandispora cornuta Higgs 1975

Grandispora senticosa (Ischenko) Byvsheva 1985

Hystricosporites spp.

Raistrickia variabilis Dolby \& Neves 1970

Retispora lepidophyta (Kedo) Playford 1976

Retispora macroreticulata (Kedo) Byvscheva 1985

Rugospora radiata (Jushko) Byvscheva 1985

Tergobulasporites immensus (Nazarenko \& Nekriata) Turnau 2002

Vallatisporites pusillites (Kedo) Dolby \& Neves 1970

\section{Figure captions}

Fig. 1. Map of the Ballagan Formation outcrop area in the Scottish Borders and North East England. The key localities of Burnmouth, Preston and Pease Bay are shown together with the Norham West Mains Farm borehole. (Green area of the Ballagan Formation is from the British Geological Survey DiGMapGB (c) NERC 2018. It contains Ordnance Survey data (C) Crown copyright and database right 2018.)

Fig. 2. Lithostratigraphic units from the Borders area correlated with the established Late Devonian and Early Carboniferous chronostratigraphy. The spore zones are shown but only the $\mathrm{Pu}, \mathrm{CM}$ and $\mathrm{VI}$ have been identified. The rest are conjectural. The current established formations are shown together with the older terminology as used in earlier literature. Largely after Waters et al. (2011). 
Fig. 3. Stratigraphic columns showing the contrasting views of Säve-Söderbergh and Westoll of fish ranges against the Devonian-Carboniferous boundary chronology. The Greenland ranges are from Säve-Söderbergh (1934). The strata in Greenland show the sequence of faunas from Phyllolepis, Remigolepis and Groenlandaspis interpreted as entirely Devonian in age. At that time the DevonianCarboniferous boundary was poorly defined with the Strunian from Belgium being variously Devonian or Carboniferous. Subsequently formal definition of the boundary has placed it in the Devonian with the Famennian extending to the base Carboniferous with the Strunian relegated to a regional stage. In Scotland only Phyllolepis was recognised. Westoll (1951) noted that this was from the uppermost part of the Scottish Devonian and below a conformable succession into the Carboniferous. Therefore, by correlation the Devonian-Carboniferous boundary in Scotland was placed below the range of Remigolepis.

Fig. 4. New compilation of the Late Devonian and Early Carboniferous lithostratigraphy from East Greenland. This shows the range of Remigolepis spp from Blom et al. (2005) plotted against the identified spore zones (GF to Pu). The Devonian-Carboniferous boundary is within the Obrutschew Formation (OBF). Compiled by direct section measurement from Astin et al. (2010) from Stensiö Bjerg and Nathorst Bjerg below the base Carboniferous and then from Celsius Bjerg for the Early Carboniferous. Other data from Marshall et al. (1999) and Vigran et al. (1999). The presence of Remigolepis ( $\mathrm{R}$ ) within a section that runs into the CM spore zone shows that the Kinnesswood Formation is Famennian and younger than early latest Famennian in age. It is placed at the top of the range of Remigolepis based on the argument that the latest Famennian glacial-interglacials are the time gap represented by the calcrete.

Fig. 5. The lowest $300 \mathrm{~m}$ of the Ballagan Formation from Burnmouth from Bennett et al. (2016) and Kearsey et al. (2016). The occurrences of key spores enabled the VI, HD and $\mathrm{Cl} 1$ spore zones to be identified. Significantly this enables application of the integrated spore and conodont zonation from Poland (Matya et al. 2010) and a better correlation to the Early Carboniferous than using the more limited data from Ireland.

Fig. 6. Logged section and annotated field photo of the contact between the Kinnesswood and Ballagan Formations, Burnmouth. The field photo is of near vertical strata with way up to the left. The uppermost Kinnesswood Formation is a cross-bedded sandstone containing small rhizocretions and abundant rootlet structures. It has a gently undulating top surface without obvious truncation and no calcretisation or pre-Ballagan Formation weathering. The Ballagan Formation is conformably bedded on this surface with cementstones present at the contact that must represent flooding by a lagoon that infilled depressions on the top of the Kinnesswood Formation. The log shows a concentration of wave ripples inter-bedded with these first cementstones again showing the presence of shallow standing water. There are dark coloured mudstones at the contact that were prepared for palynology but only residual black phytoclasts were present.

Fig. 7. Illustration of important stratigraphic spores from Burnmouth (1-10) and the Whiteadder at Preston (11-20). All figured spores are in the palynology collections of the BGS, Keyworth. Microscope co-ordinates refer to Olympus BHS-313 No. 210685 in the School of Ocean and Earth Science, University of Southampton. England Finder co-ordinates (e.g. R20-2) are also provided.

1. Plicatispora scolecophora, Burn W-10 W Hbr 14, $(130,10), \mathrm{S} 29-2 \times 750$

2. Retusotriletes sp, Burn W-10 W Hbr 27, (121, 11), R20-2, x750

3. Cristatisporites hibernicus, Burn 13-6 W Hbr 45, (125.1, 7.4), U24-4, x750

4. Grandispora upensis, Burn 12-10 E Hbr 10, $(125.7,10.8), \mathrm{R} 25-4, x 750$

5. Claytonispora distincta, Burn 13-6 W Hbr 22, (126.1, 16), M25-2, x750 
6. Neoraistrickia cymosa, Burn 12-10 E Hbr 1, $(125.3,10.2)$, S25-1, x750

7. Prolycospora claytonii, Burn 16-4 E Hbr 3, $(118.2,12.6)$, P17-4, x1000

8. Prolycospora claytonii, Burn 16-4 E Hbr 3, $(116,14.8), \mathrm{N} 15-4, \mathrm{x} 1000$

9. Schopfites delicatus, Burn 12-10 WH 14, $(129.5,13.7), 029-1, x 750$

10. Schopfites spp approaching S. claviger in size of sculpture, Burn W Hbr 40, $(121.8,14.6), \mathrm{N} 21-4$, x750

11. Anapiculatisporites baccatus, Burn $12-10$ S Cliffs $215,(125.9,10.3)$, S25-2, x500

12. Retispora lepidophyta, Preston 17-5-4 (3), (121.2, 11), R21-1, x750

13. Vallatisporites pusillites, Preston 17-5-4 (4), $(126,6.7), \mathrm{V} 25-4, x 500$

14. Diducites versabilis, Preston 17-5-4 (3), $(114.7,23)$, D14-3, $x 500$

15. Tergogobulasporites immensus, Preston 17-5-4 (3), (133.7, 19.8), x250

16. Rugospora radiata, Preston 17-5-5 (3), (117.8, 7.1), x500

17. Isolated bifurcate spine, Preston 17-5-4 (2), (114.6, 21.5), x250

18. Retispora macroreticulata, Preston 17-5-4 (2), (111.6, 3.7), x500

19. Ancyrospora with multifurcate spines, Preston 17-5-4 lc (3), (113.6, 11.8), x250

20. Isolated spine from megaspore sized Nikitinsporites, Preston 17-5-4lc (3), (139, 16.9), x250

21. Hystricosporites with bifurcate tipped spines, Preston 17-5-4 (3), (120.6, 12), x250

Fig. 8. Measurements of the mean height and width of the sculpture of two populations of Schopfites from Burnmouth. The specimens with smaller sculpture (the mean is the 6 point star) are from 71.85 $\mathrm{m}$ and assigned to $S$. delicatus. The larger sculpture is from $257.9 \mathrm{~m}$ within the $\mathrm{Cl} 1$ zone and approaching that of $S$. claviger in size. The mean is the open cross. Measurement as per Higgs et al. (1988) except that the means are from multiple sculptural elements on individual spores rather than means of many spores from multiple samples.

Fig. 9. Range chart of spores from the productive Kinnesswood Formation sample in the Whiteadder at Preston. The sample is clearly Devonian in age as Retispora lepidophyta, Ancyrospora spp., Hystricosporites spp., Nikitinsporites spp., Rugospora radiata, Diducites versabilis and Vallatisporites pusillites all become extinct exactly at the Devonian-Carboniferous boundary. The age is more specifically latest Devonian from the range base of Retispora lepidophyta. Retispora macroreticulata becomes extinct (Maziane et al. 1999) in the very base of the LL zone also constraining the age. Tergobulasporites immensus further constrains the age to early latest Famennian as it is not reported to overlap the age range of $R$. lepidophyta. The absence of Indotriradites explanatus and Verrucosisporites nitidus supports an assignment to the LL spore zone rather than LE or LN.

Fig. 10. Lithostratigraphic correlation between Carham, the poorly exposed new locality with early latest Famennian spores from the Whiteadder Water at Preston and Pease Bay. Carham log based on information in Carruthers et al. (1932). Pease Bay from our own data. The Carham Limestone is a thick single Stage 6 calcrete with a chert core that correlates with the Stage 6 calcrete at Pease Bay. The calcrete is present above the Kelso Lavas at Carham and Preston where it is only represented by one flow (Tomkieff, 1945). The mudstone with early latest Famennian spores from Preston contain volcaniclastic debris and are correlative with part of the Kelso Lavas.

Fig. 11. Revised stratigraphy of the Late Devonian to Early Carboniferous interval in the Borders. The new interpretation shows a much extended Ballagan Formation that extends through the entire Tournaisian. The base approximates to the base of the VI spore zone and above a hiatus or condensed horizon. The Kinnesswood Formation and other 'ORS' formations are entirely Devonian in age. Spore 
zones proved to be present in the sections are shown in bold. LE and LN have not been identified. The previous age shows a more condensed Ballagan Formation equivalent to the $\mathrm{CM}$ spore zone and entirely late Tournaisian in age. In the Burnmouth section the Fell Sandstone Formation lies above an erosive gap and approximates the base of the Pu spore zone of Viséan age.
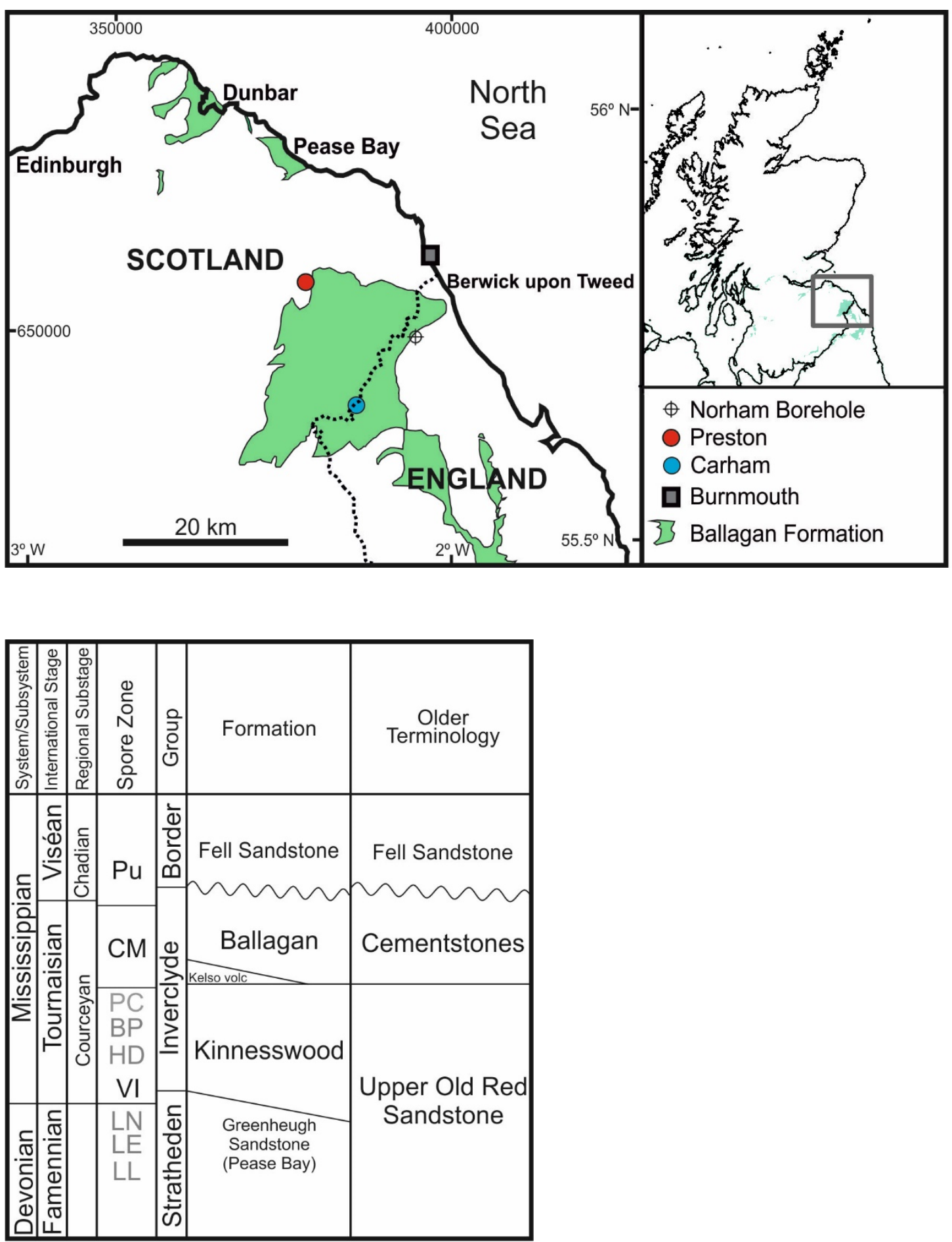


\section{Greenland}

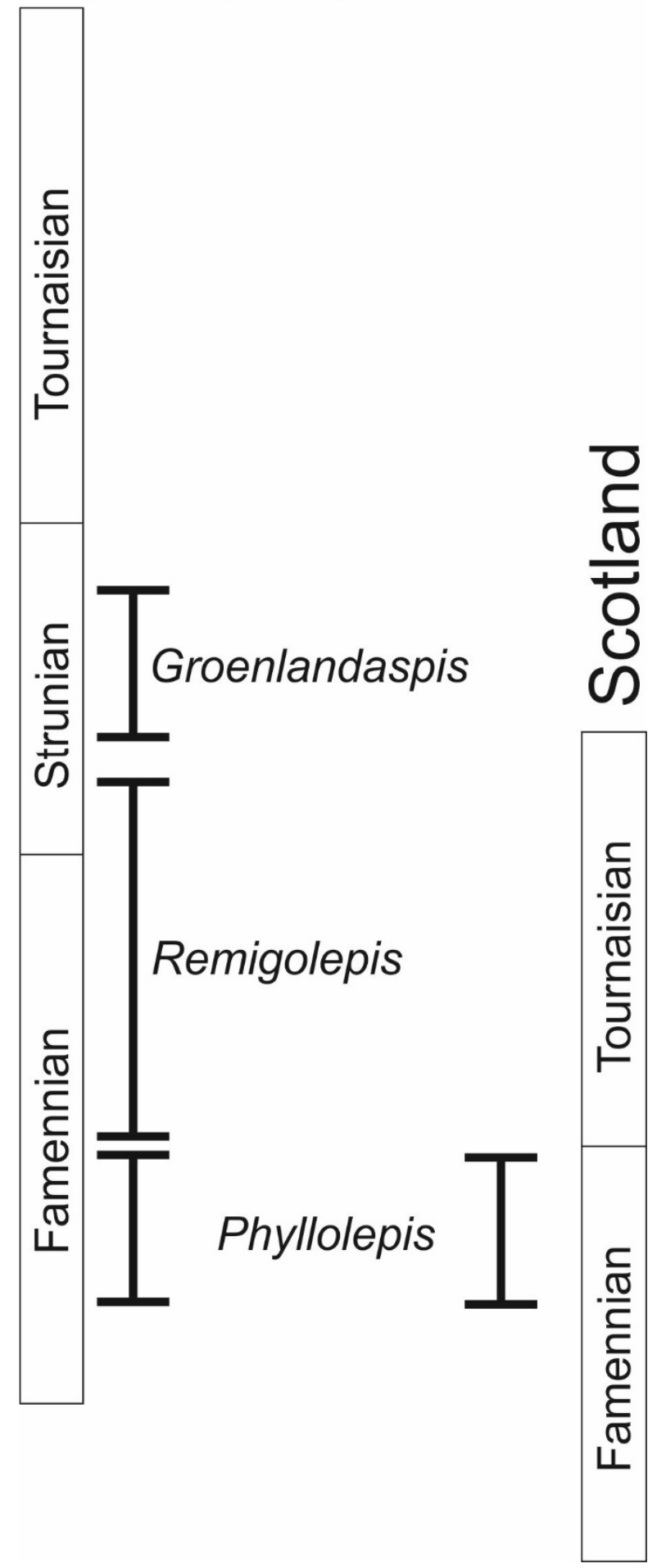


East Greenland

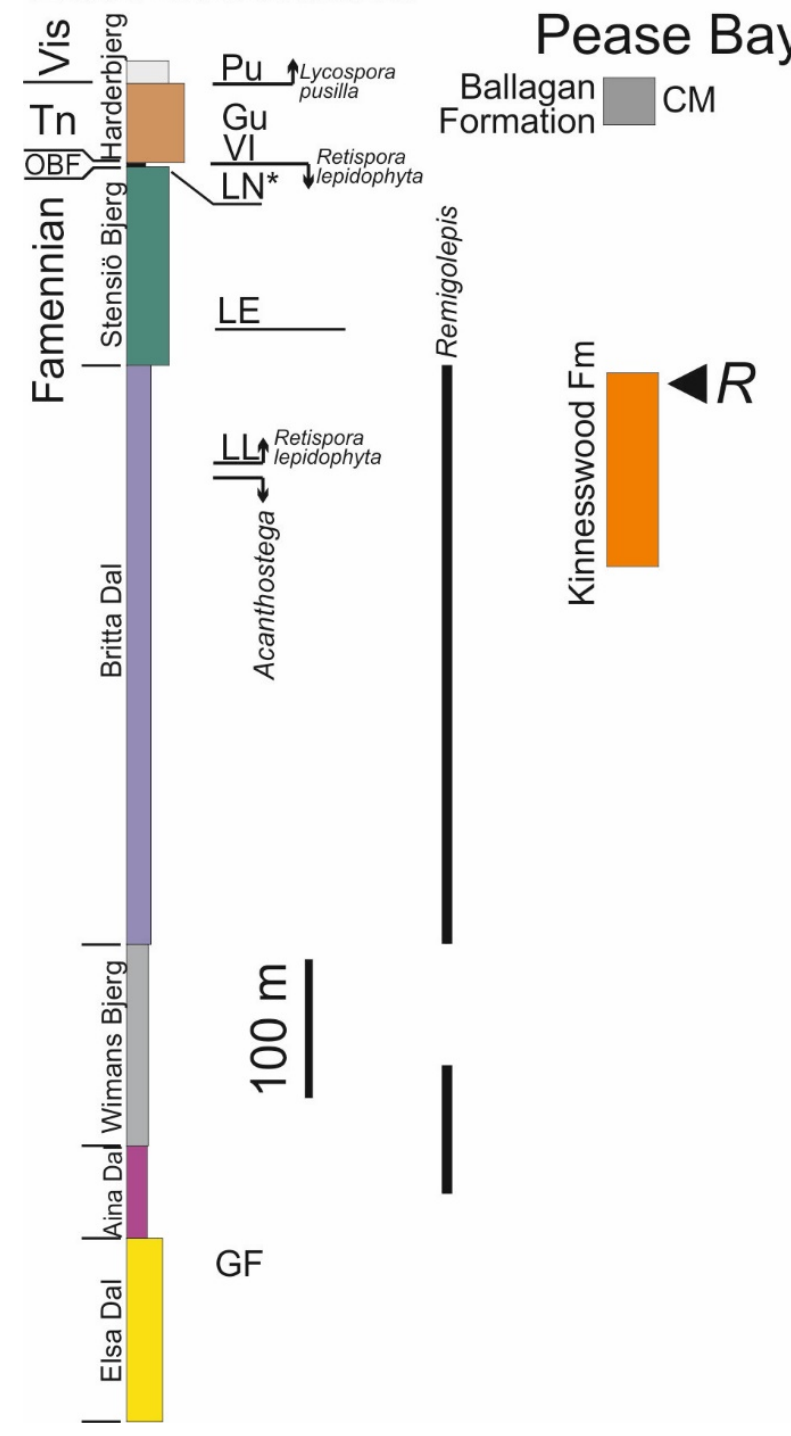



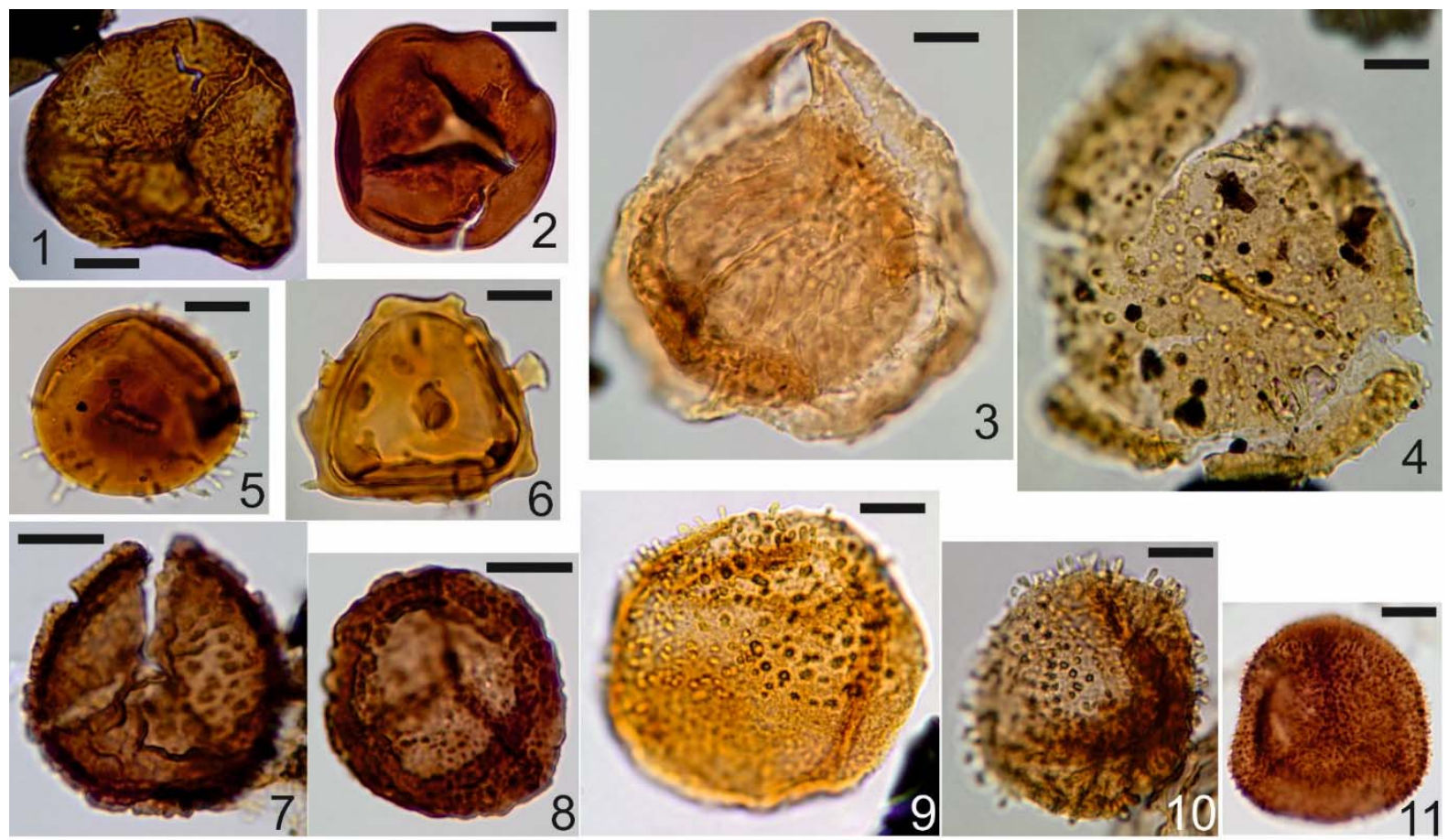

\section{$10 \mu \mathrm{m}=\times 200=\times 250-\times 500-x 750-\times 1000$}

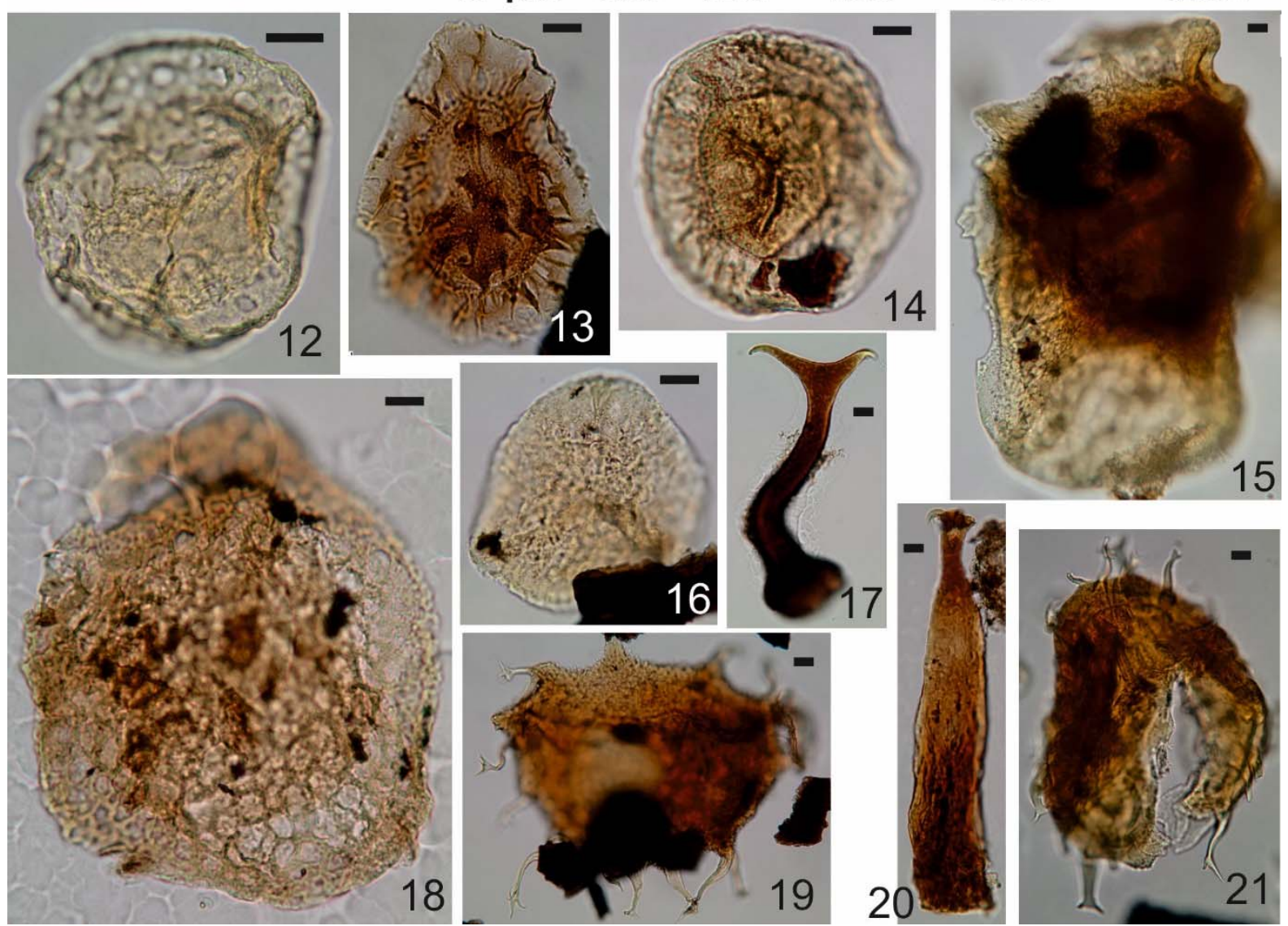



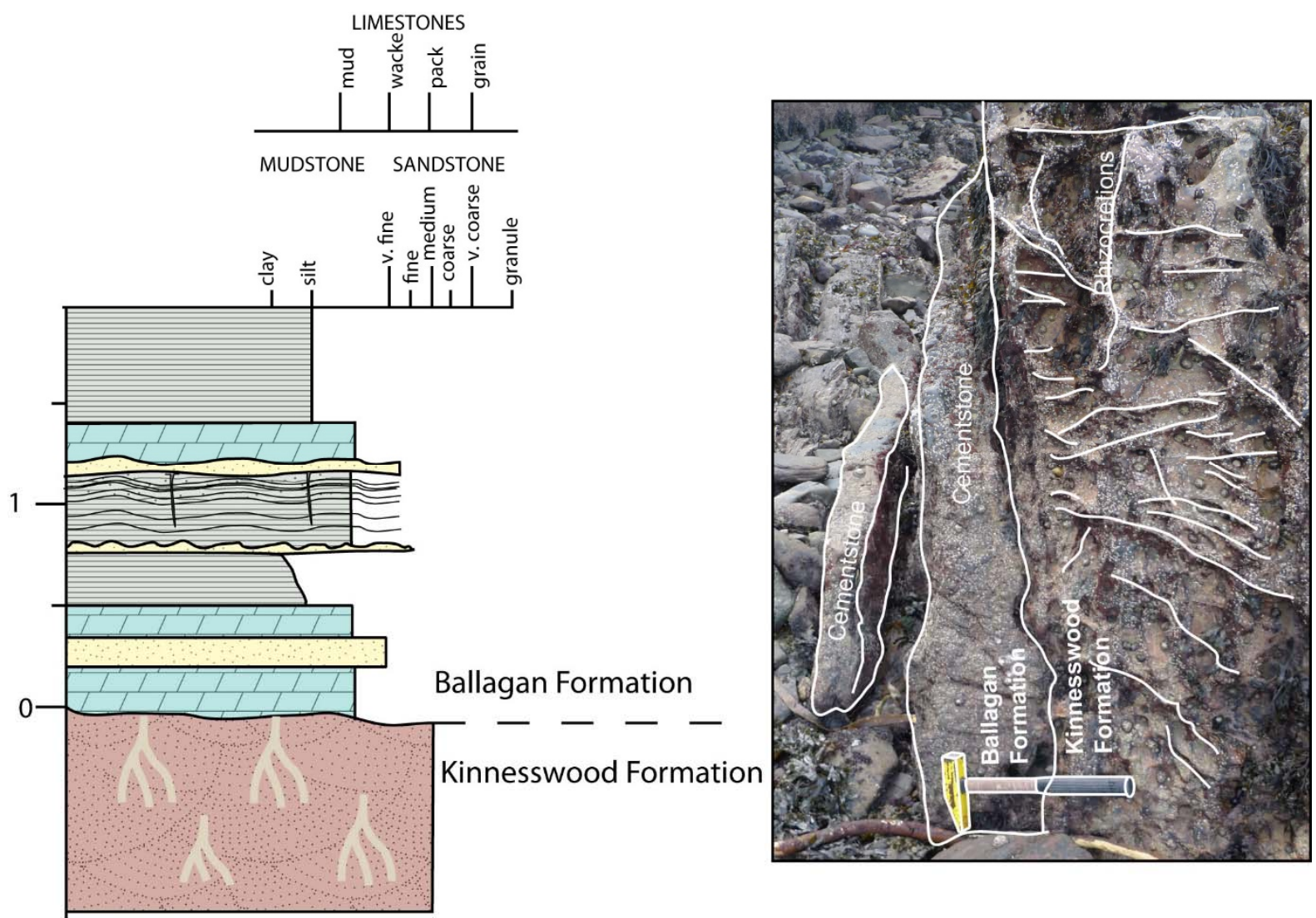

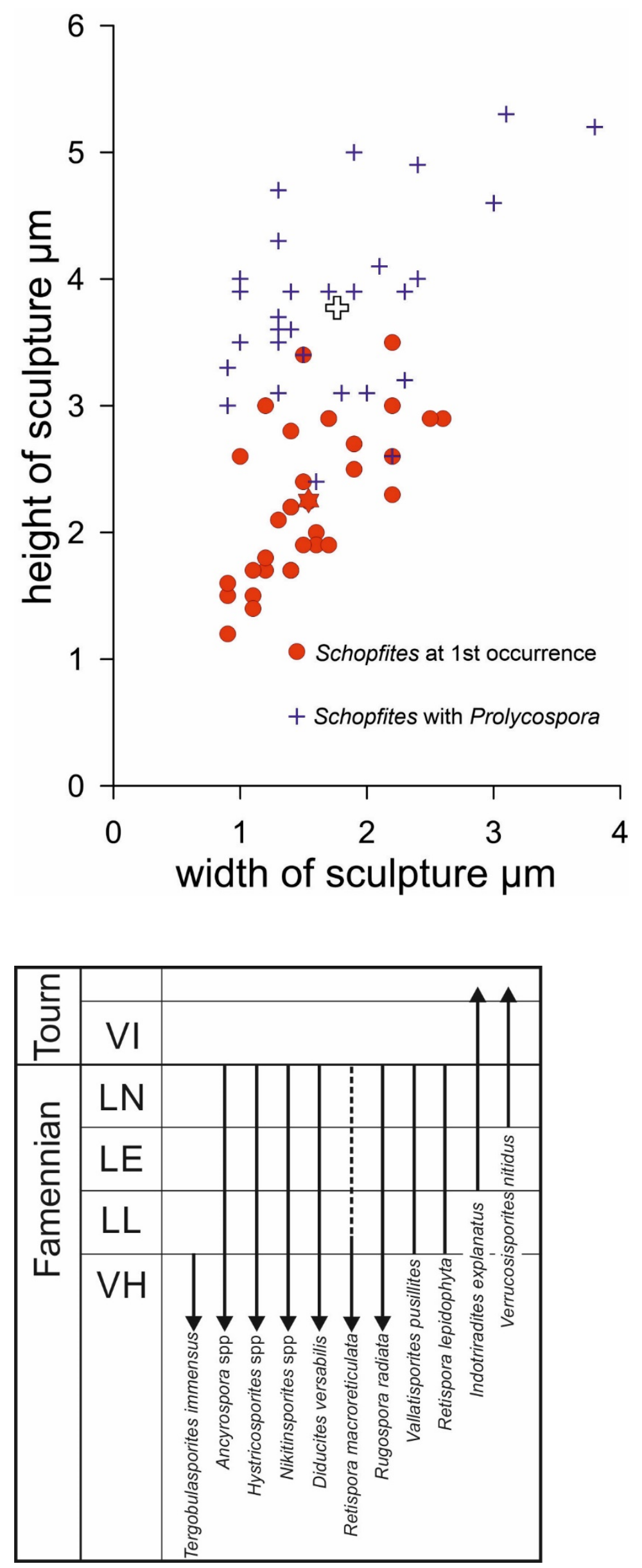


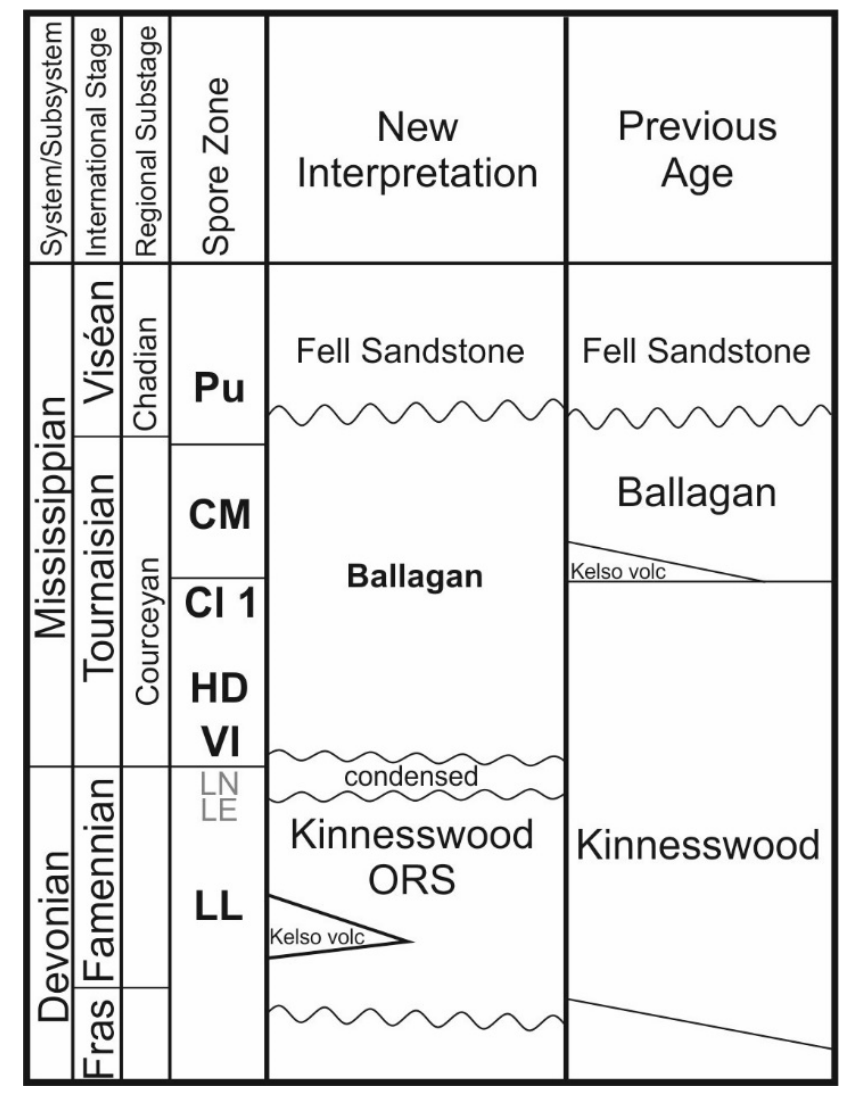




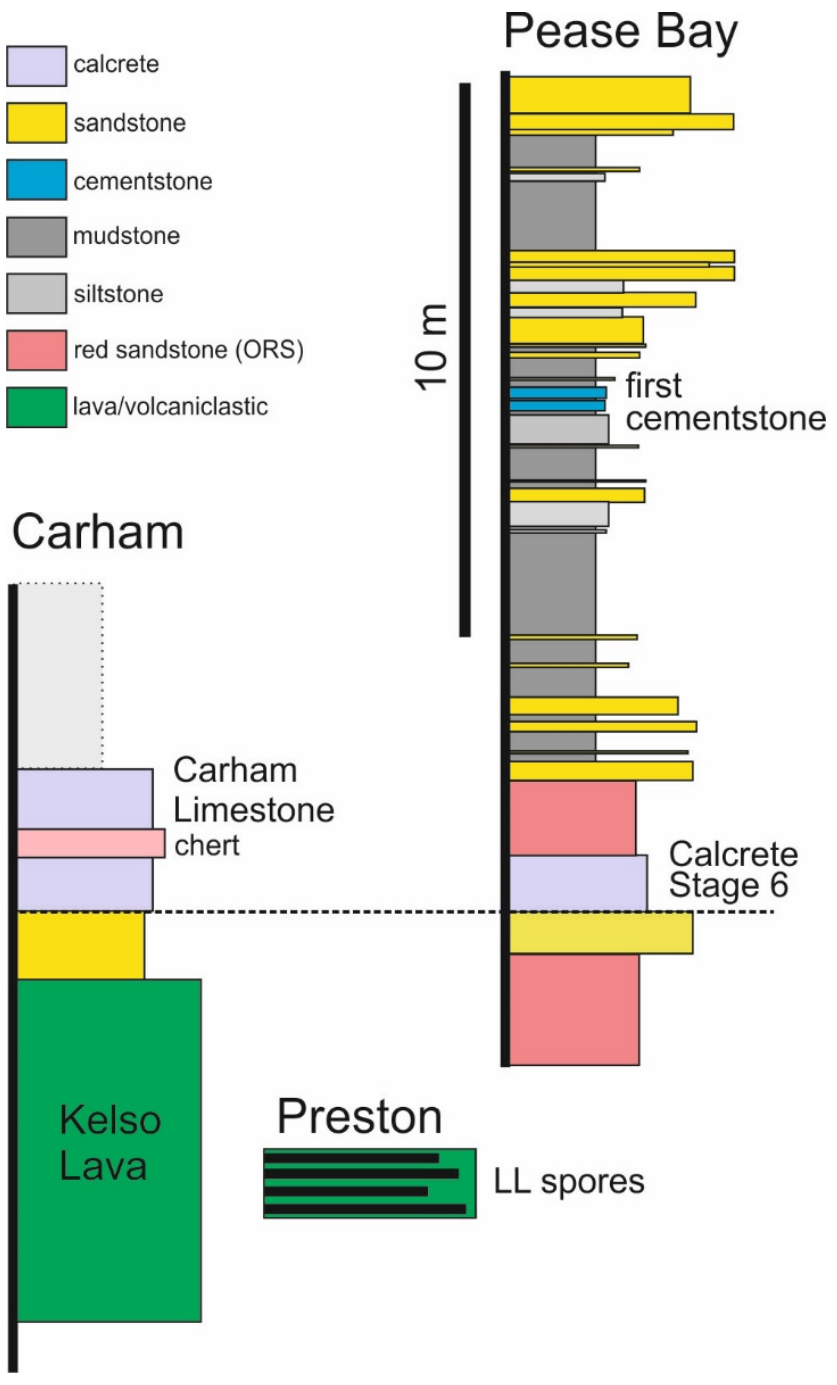

